УДК 338.439

Герасимчук 3.В., д.е.н., професор

https://orcid.org/0000-0002-3676-4147

Gerasymchuk Z. Doctor of Economics, Professor

Гасуха Л.О., здобувач

Gasukha L. Applicant

https://orcid.org/0000-0003-1454-5696

\title{
ПРОДОВОЛЬЧИЙ БАЛАНС ТА РЕГІОНАЛЬНИЙ СТРАХОВИЙ ЗАПАС ЯК ІНСТРУМЕНТИ МЕХАНІЗМУ ЗАБЕЗПЕЧЕННЯ ПРОДОВОЛЬЧОЇ БЕЗПЕКИ РЕГІОНІВ
}

\author{
Луияький національний технічний університет
}

У публікації підлягають розгляду питання щодо особливостей застосування регіональних інструментів забезпечення продовольчої безпеки в умовах децентралізації влади. Пропонується власний підхід до формування страхових запасів продовольства в регіоні з метою гарантування продовольчої безпеки - одного з пріоритетних завдань регіональних органів управління в період сучасних трансформаційних процесів. На основі аналізу чинників щодо ситуації на ринку продовольства регіонів України можна констатувати, що причини впливу негативних факторів на рівень продовольчої безпеки мають виражений регіональний характер, тому саме територіальний аспект визначає ключові фактори регіональної політики за допомогою реалізації відповідного механізму продовольчого забезпечення. За єдиної для всіх регіонів мети - забезпечення належного рівня продовольчої безпеки, інструменти іiі досягнення будуть різними для різних груп регіонів в залежності від того, на якій стадії продовольчого забезпечення за кожним із індикаторів, що характеризує його рівень, перебуває той чи інший регіон. Аналіз споживання основних видів продукції в регіонах України за останні десять років свідчит, що населення споживало лише 66 відсотків раціональної норми м'яса та м'ясопродуктів, 55 - молока, 58 відсотків риби. Із продукції рослинництва недостатнім $\epsilon$ споживання плодів, потреба в яких забезпечувалася лише на 60 відсотків. Головне завдання механізму продовольчого забезпечення урегулювання відносин між учасниками ринку продовольства (виробниками, постачальниками та споживачами) для гарантування належного рівня продовольчого забезпечення населення регіону якісними й доступними за ціною продуктами харчування. Зроблено висновок, що застосування балансового методу дасть змогу не лише визначити відсоток забезпечення внутрішніх потреб власною продукцією, а й виявити шляхи забезпечення фондів споживання за рахунок внутрішніх чи зовнішніх джерел. Формування регіональних страхових запасів продовольства на основі балансового методу допоможе сформувати дієвий механізм продовольчого забезпечення на рівні регіонів в умовах децентралізації влади та передачі повноважень щодо забезпечення продовольчої безпеки із центрального на регіональний рівень.

Ключові слова: регіональний страховий запас продовольства, продовольчий баланс, пропозиція та потреба продовольства, інтервениіииний фонд.

\section{FOOD BALANCE AND REGIONAL RESERVES AS TOOLS OF FOOD SECURITY MECHANISM IN REGIONS}

\author{
Lutsk National Technical University
}

The subject of this article is the consideration the peculiarities of the application of regional instruments of food security in the context of decentralization of power. Proposed own approach to the formation of food reserves at the regional level to ensure food security as one of the priority tasks of regional authorities in the period of modern transformation processes. Based on the analysis of factors of the food market of the regions of Ukraine, it can be stated that the reasons for the impact of negative factors on the level of food security are regional, so the territorial aspect determines the key factors of regional policy through the implementation of appropriate food security mechanism. With the same goal for all regions - to ensure the appropriate level of food security, the tools to achieve it will be different for different groups of regions depending on the indicators that determine the level of food security at each stage. The analysis of consumption of the main types of products in the regions of Ukraine for the last ten years shows that the population consumed only 66 percent of the rational norm of meat and meat products, 55 percent of milk, 58 percent of fish. Consumption of fruits, the need for which was met by only 60 
percent, is insufficient. The main task of the food supply mechanism is to regulate the relations between the participants of the food market (producers, suppliers and consumers) to guarantee the proper level of food supply of the population of the region with quality and affordable food. It is concluded that the application of the balance method will allow not only to determine the percentage of domestic demand for own products, but also to identify ways to form consumption funds using internal or external sources. The formation of regional food reserves on the basis of the balance method will help to form an effective mechanism of food provision at the regional level in the context of decentralization of power and transfer the responsibilities to ensure food security from the central to the regional level.

Keywords: regional food reserves, food balance, food supply and demand, intervention fund.

Постановка проблеми у загальному вигляді та їі зв'язок 3 важливими науковими та практичними завданнями. Забезпечення продовольчої безпеки регіонів України є проблемою, яка щороку набирає все більшої актуальності, особливого значення це питання набуло в період пандемії COVID-19. Існує необхідність налагодження співробітництва регіонів для забезпечення продовольчої безпеки, зокрема й доступності населення до продуктів харчування, у відповідь на пандемію коронавірусної інфекції. Важливим регіональним завданням є забезпечення населення регіону якісними продуктами харчування в обсягах, що відповідають раціональним нормам споживання. Дієвим інструментом врівноваження попиту i пропозиції, моделювання ситуації на ринку продовольства $\epsilon$ складання балансів продовольчих ресурсів. Прогнозні баланси характеризують очікувані джерела надходження ресурсів основних видів продовольства та канали їх використання, надають можливість моделювати ситуацію на ринку продовольства, визначати необхідні обсяги нарощування виробництва та шляхи формування фонду споживання продукції. На підставі сформованих балансів, визначаються канали розподілу продовольства, а також способи розширення експортного потенціалу. Своєчасність та точність інформації щодо наявності сільськогосподарської та харчової продукції, обсягів виробництва, споживання та запасів, а також цін зменшує невизначеність і дозволяє регіональним органам влади, трейдерам, споживачам і виробникам приймати обгрунтовані рішення.

Аналіз останніх досліджень у яких започатковано вирішення проблеми. Проблемі продовольчої безпеки регіону та регіональним інструментам іï забезпечення присвятили роботи такі науковці, як: Н. Басюркіна, В. Береговий, І. Бодак, І. Вахович, О.Гойчук, 3. Ільїна, Є. Калашнікова, О. Коломицева, О. Кочеткова, Р. Маркова, В. Микитюк, М. Місюк, Н. Саперович, О. Скидан, Б. Стефанишин, Л. Хромушина, О. Чечелі, О. Шевцова, В. Шлемко та інші.

Однак, аналіз робіт вчених показує, що регіональні інструменти формування регіональних страхових запасів продовольства, що $є$ особливо актуальними в період пандемій чи карантинних обмежень, розкриті недостатньо і потребують подальшого вивчення в науковому та практичному аспектах.

Цілі статті. Мета дослідження полягає у вивченні тенденцій у формуванні регіональних страхових запасів продовольства для виявлення проблемних питань та дієвих інструментів гарантування продовольчої безпеки на регіональному рівні.

Виклад основного матеріалу дослідження 3 повним обгрунтуванням отриманих наукових результатів. Як зазначалося, прогнозні та фактичні баланси продовольства дають змогу оцінити споживання продукції та рівень забезпечення мінімальних та раціональних норм харчування. На підставі прогнозних балансів приймаються рішення щодо планування виробництва, забезпечення імпортозаміщення продукції, розробляються інвестиційні та інноваційні програми, плани фінансування.

Визначити пропозицію та потребу регіону у основних видах продовольства та частку забезпечення внутрішніх потреб продукцією, виробленою в регіоні дає змогу продовольчий баланс, який включає пропозицію продукції та потребу регіону. Різниця між попитом та пропозицією дає змогу виявити очікувані залишки продовольства на 
кінець аналізованого періоду та експортні можливості регіону.

В свою чергу пропозиція кожного виду продукції в регіоні складається із обсягу його внутрішнього виробництва та надходження продукції з інших регіонів та ії імпорт.

Потреба відображена в балансі за напрямками використання продукції, які різняться для різних видів продовольства.

Продовольчий баланс доцільно розробляти на рік, враховуючи специфіку продукції рослинництва, яка надходить на ринок у період збору урожаю, тому зокрема для зернових рекомендовано розраховувати баланс на маркетинговий період (з першого липня поточного року до 30 червня наступного року). Можливим також є складання балансів продовольства й на інші календарні періоди (місячні, квартальні, піврічні).

Оскільки різні категорії виробників задіяні в процесі формування продовольчих ресурсів розгорнуті баланси можуть відображати джерела формування на напрями використання продовольства за категоріями виробників.

При складанні балансу зернових важливо відображати частку продовольчого зерна, адже напрямок використання зерна в першу чергу залежить від його якісних характеристик. Таким чином продовольче зерно використовується для потреб хлібопечення, на насіння, частково на нехарчові цілі та може бути реалізовано за межі області. Непродовольче зерно (фуражне) використовується, в основному, на корм худобі.

Основна мета складання продовольчих балансів - виявити чи дозволить пропозиція продукції в регіоні забезпечити внутрішні потреби на певний період. Окрім деталізованих продовольчих балансів пропонується використовувати спрощений підхід до їх підготовки, який дозволяє визначити частку забезпечення внутрішніх потреб продукцією, вирощеною в регіоні.

Приклад спрощеного підходу до розрахунку балансу (табл. 1).

Таблиця 1

Баланс зернових та зернобобових культур у Волинській області за 2016-2019 маркетингові роки

\begin{tabular}{|l|c|c|c|c|}
\hline & ум. познач. & $\mathbf{2 0 1 6 / 1 7} \mathbf{M P}$ & $\mathbf{2 0 1 7 / 1 8}$ MP & $\mathbf{2 0 1 8} / \mathbf{1 9}$ MP \\
\hline Виробництво & $\mathbf{P}$ & $\mathbf{7 0 3 . 3}$ & $\mathbf{7 9 3 . 9}$ & $\mathbf{8 3 0 . 2}$ \\
\hline Зміна запасів на кінець року & $\mathbf{Z}$ & -70.7 & -2.9 & 23.1 \\
\hline Надходження & $\mathbf{I}$ & 132.9 & 120.5 & 173.8 \\
\hline Всього ресурсів & & $\mathbf{7 6 5 . 5}$ & $\mathbf{9 1 1 . 5}$ & $\mathbf{1 0 2 7 . 1}$ \\
\hline Реалізовано за всіма напрямами & $\mathbf{E}$ & 145.2 & 235.5 & 330.7 \\
\hline Витрачено на посів & $\mathbf{N}$ & 53.6 & 54.4 & 56 \\
\hline Витрачено на корм & $\mathbf{K}$ & 305.0 & 382.4 & 400.3 \\
\hline Втрати & $\mathbf{V}$ & 12.4 & 14.3 & 16.8 \\
\hline Переробка на нехарчові цілі & & 105.8 & 77.8 & 77.8 \\
\hline Витрачено зерна для споживання & & 143.5 & 147.1 & 145.5 \\
\hline Фонд споживання хлібних продуктів & $\mathbf{S}$ & 107.6 & 110.3 & 109.1 \\
\hline \multicolumn{1}{|c|}{$\boldsymbol{y}$ розрахунку на 1 особу, кг } & & $\mathbf{1 0 3 . 5}$ & $\mathbf{1 0 6 . 4}$ & $\mathbf{1 0 5 . 6}$ \\
\hline $\begin{array}{l}\text { Відсоток забезпечення внутрішніх } \\
\text { потреб власною продукцісю }\end{array}$ & $\mathbf{W}$ & $\mathbf{1 0 2 . 0}$ & $\mathbf{1 1 7 . 0}$ & $\mathbf{1 2 2 . 5}$ \\
\hline
\end{tabular}

Мінімальна норма споживання

Раціональна норма споживання 94

* Розраховано автором за даними [8]

Хоча спрощений підхід до розрахунку не містить розподілу за категоріями виробників, однак він дає змогу відслідкувати формування та розподіл продукції, тобто охоплює усі стадії забезпечення продовольчої безпеки (від виробництва да споживання).

За таким зразком розраховується баланс усіх зернових культур (пшениці, жита, ячменю, кукурудзи та інших зернових). 
Зерно історично є стратегічним продуктом у забезпеченні продовольчої безпеки.

Відповідно до постанови Кабінету Міністрів України від 05.12.07 № 1379 «Деякі питання продовольчої безпеки» [1] достатність запасів зерна у державних ресурсах використовується як один із основних індикаторів забезпечення продовольчої безпеки, що визначається як співвідношення між обсягами продовольчого зерна у державному продовольчому резерві та обсягами внутрішнього споживання населенням хліба і хлібопродуктів у перерахунку на зерно.

На виконання зазначеної постанови, регіональні ресурси продовольчого зерна формувалися в регіонах щорічно в середньому в обсязі 33 відсотків від фонду споживання (табл. 2).

Таблиця 2

Формування регіональних ресурсів продовольчого зерна*

\begin{tabular}{|c|c|c|c|}
\hline Область & $\begin{array}{c}\text { Річний обсяг } \\
\text { формування } \\
\text { регіональних ресурсів } \\
\text { продовольчого зерна, } \\
\text { тис. т }\end{array}$ & $\begin{array}{c}\text { Річний фонд споживання } \\
\text { хлібних продуктів, } \\
\text { тис. } m\end{array}$ & $\begin{array}{c}\text { Співвідношення } \\
\text { регіональних } \\
\text { ресурсів } \\
\text { до фонду спо- } \\
\text { живання, \% }\end{array}$ \\
\hline Україна & 1700 & 5046,8 & 33,7 \\
\hline АР Крим & 89 & 266,9 & 33,3 \\
\hline Вінницька & 67 & 199,3 & 33,6 \\
\hline Волинська & 45 & 132,4 & 34,0 \\
\hline Дніпропетровська & 119 & 350,5 & 34,0 \\
\hline Донецька & 158 & 464,0 & 34,1 \\
\hline Житомирська & 52 & 145,8 & 35,7 \\
\hline Закарпатська & 51 & 151,1 & 33,8 \\
\hline Запорізька & 63 & 191,5 & 32,9 \\
\hline Івано-Франківська & 53 & 160,5 & 33,0 \\
\hline Київська разом із м. Київ & 128 & 380,1 & 33,7 \\
\hline Кіровоградська & 38 & 113,4 & 33,5 \\
\hline Луганська & 89 & 255,2 & 34,9 \\
\hline Львівська & 89 & 269,4 & 33,0 \\
\hline Миколаївська & 49 & 141,8 & 34,6 \\
\hline Одеська & 89 & 276,0 & 32,2 \\
\hline Полтавська & 59 & 174,3 & 33,8 \\
\hline Рівненська & 44 & 134,0 & 32,8 \\
\hline Сумська & 47 & 132,6 & 35,4 \\
\hline Тернопільська & 43 & 124,4 & 34,6 \\
\hline Харківська & 100 & 299,6 & 33,4 \\
\hline Херсонська & 44 & 140,5 & 31,3 \\
\hline Хмельницька & 47 & 141,3 & 33,3 \\
\hline Черкаська & 55 & 161,2 & 34,1 \\
\hline Чернівецька & 36 & 107,4 & 33,5 \\
\hline Чернігівська & 46 & 133,6 & 34,4 \\
\hline $\begin{array}{l}\text { Коефіцієнт міжрегіональних } \\
\text { диференціачій }\end{array}$ & 4.4 & 4.3 & \\
\hline
\end{tabular}

* Розраховано автором за даними [9]

Як видно 3 табл. 2, коефіцієнт міжрегіональних диференціацій формування регіональних ресурсів становив 4.4, що свідчить про суттєву відміність регіонів за обсягом формування запасів продовольчого зерна, найбільший з яких був сформований в Донецькій області (158 тис. т.), найменші - у Чернігівській (36 тис. т). Така 
диференціація пояснюється різницею у фондах споживання хлібних продуктів.

Сформовані фонди регіональних ресурсів продовольчого зерна забезпечували потребу у споживанні та дозволяли гарантували продовольчу безпеку регіону.

Однак, з прийняттям Закону України «Про внесення змін до деяких законів України щодо вдосконалення механізмів державного регулювання ринку сільськогосподарської продукції» [2] у численних нормативних актах термін «продовольчий резерв» було замінено терміном «інтервенційний фонд», а словосполучення «державний резерв» - на «державний інтервенційний фонд». Вищевказаний закон доповнив Закон України «Про державну підтримку сільського господарства України» [3], зокрема, визначенням поняття «державний інтервенційний фонд» - фонд, який формується Аграрним фондом за рахунок фінансових інтервенцій, заставних, форвардних і ф'ючерсних закупівель та використовується для здійснення товарних інтервенцій з метою забезпечення цінової стабільності.

Повноваження з реалізації фінансових інтервенцій на організованому аграрному ринку, заставних, форвардних та ф'ючерсних закупівель об'єктів державного цінового регулювання були надані Аграрному фонду Постановою КМУ від 23 червня 2010 р. N 503 «Про затвердження Порядку використання коштів, передбачених у державному бюджеті на формування Аграрним фондом державного інтервенційного фонду» [4].

Оскільки Аграрний фонд - це акціонерне товариство, провідний оператор аграрного сектору України, метою діяльності якого є створення сприятливих умов для розвитку сільського господарства, функціонування ринку сільськогосподарської продукції, підтримки вітчизняного сільськогосподарського товаровиробника, а також одержання прибутку від провадження господарської діяльності відповідно до законодавства, то ресурси, сформовані Аграрним фондом, не гарантують продовольчу безпеку держави в повній мірі, а їх регіональний розподіл взагалі відсутній.

Із 1 липня 2014 року . регіональні ресурси продовольчого зерна не формуються в Україні на державному рівні, оскільки із Закону України N 37-IV «Про зерно та ринок зерна в Україні» [5] була вилучена стаття 17, яка визначала передумови формування регіональних ресурсів шляхом укладення угод на акредитованих біржах за рахунок коштів бюджету областей в межах визначених ними обсягів.

У пояснювальній записці до проєкту Закону про скасування статті 17 Закону України «Про зерно та ринок зерна в Україні» зазначено, що «прийняття законопроекту дозволить зменшити кількість перешкод для пересування зерна територією України, знизить адміністративний тиск на аграріїв, при цьому в Україні продовжить функціонувати більш ефективний механізм забезпечення стабільних цін на хліб - реалізація Аграрним фондом борошна хлібопекарським підприємствам за фіксованими цінами для виробництва хліба масового вжитку». На нашу думку, це твердження суперечливе, оскільки, по-перше, відмова від формування регіональних ресурсів зерна знімає відповідальність 3 місцевих органів влади за формування необхідних запасів продовольчого зерна, що є стратегічним продуктом у гарантуванні продовольчої безпеки регіону; по-друге, стаття 17 Закону жодним чином не обмежувала пересування зерна територією України; по-третє, Аграрний фонд, як зазначалося, згідно зі статутними документами, $є$ приватним акціонерним товариством, основною метою діяльності якого $є$ отримання прибутку, що не гарантує проведення державних інтервенцій на ринку зерна та борошна. Зважаючи на наведені факти та процеси децентралізації влади в Україні існує об’єктивна необхідність формування резервних запасів продовольства на регіональному рівні.

Потребу регіону у обсягах формування регіонального страхового запасу продовольства доцільно визначати за формулою (1):

$$
P i=C i * \Gamma i
$$

де: $\mathrm{Pi}$ - потреба у формуванні регіонального страхового запасу і-го виду продовольства; 
Гi - граничний критерій забезпечення регіону за i-м видом продовольчих ресурсів;

$\mathrm{Ci}$ - середньорічне споживання і-го виду продовольства в регіоні;

і - види продовольства, за якими формуються регіональні страхові запаси продовольства.

Види продовольства, за якими формуються регіональні страхові запаси визначаються місцевими органами влади. Пропонується формування регіональних запасів за такими основними групами продовольства: зернові; картопля; овочі, фрукти; цукор; олія; м'ясо; молоко; риба; яйця. Однак, стратегічною в регіонах є потреба у формуванні регіонального страхового запасу продовольчого зерна. Науково обгрунтованим граничним (пороговим) критерієм для формування регіональних страхових запасів продовольства $\epsilon$ його 17-відсотковий рівень, що відповідає 60 дням споживання (на основі міжнародного досвіду та досвіду формування продовольчих запасів на державному рівні). В цьому випадку формула розрахунку має вигляд (2):

$$
P i=C i * 17 \%
$$

Місцевими органів влади при прийнятті регіональних програм формування регіональних страхових запасів продовольства граничний критерій може бути змінено, а також можливим $\epsilon$ встановлення диференційованих граничних критеріїв для різних видів продовольства. Також період оновлення регіонального страхового запасу буде різним для різних видів продовольства, зокрема для продукції тваринництва - м'яса, молока та яєць він буде коротшим.

Індикатор достатності продовольства в регіональному страховому запасі, пропонуємо визначати як співвідношення між обсягами сформованого запасу продовольства й обсягами внутрішнього споживання цього виду продовольства населенням регіону (3):

$$
I i=\frac{3 i}{C i} * 100 \%
$$

де: Ii - індикатор достатності запасу і-го виду продовольства;

3i - сформований регіональний страховий запас і-го виду продовольства;

$\mathrm{Ci}$ - середньорічне споживання і-го виду продовольства в регіоні.

Якщо значення індикатора достатності досягає або перевищує значення граничного (порогового) критерію слід говорити про забезпечення продовольчої безпеки в регіоні.

Оскільки регіональний страховий запас продовольчого зерна має першочергове значення для гарантування продовольчої безпеки, ряд регіоні приймають регіональні програми та передбачають відповідне фінансування їх реалізації.

Зернове господарство постачає сировину багатьом галузям переробної промисловості та $\epsilon$ основою функціонування й розвитку борошномельної, комбікормової, спиртової й інших галузей.

Необхідність нарощення в регіонах поголів'я ВРХ та птиці збільшує потребу в концентрованих кормах. Існує необхідність забезпечення якісного насіннєвого матеріалу, закупівлі продовольчого зерна до Аграрного фонду України. Щорічно зростають обсяги експорту продовольчого зерна, вирощеного в регіонах. Ці й низка інших чинників можуть призвести до дефіциту продовольчого зерна в регіоні, а також до подорожчання кінцевого продукту - хліба. Тому існує необхідність у формуванні регіональних страхових запасів зерна, щоб не допустити різкого підвищення цін на борошно для хлібопечення та затверджувати їх відповідними рішеннями місцевих органів влади.

Таке рішення було прийнято Волинською обласною радою від 24.05.13 №19/4, яким затверджено Програму створення регіонального страхового запасу продовольчого зерна у Волинській області на 2013-2014 рр. та наступні маркетингові періоди, що дозволяє сформувати регіональний страховий запасу продовольчого зерна та здійснити 
вплив на стабілізацію ситуації на ринку зерна, борошна, хліба й хлібо булочних виробів [6].

Заготівля продовольчого зерна зернопереробними, хлібозаготівельними та хлібопекарськими підприємствами області (операторами) проводиться шляхом укладання угод на акредитованих біржах, що уможливлює встановлення справедливих цін на ринку зерна.

Для визначення потреби у формуванні регіонального страхового запасу продовольчого зерна був використаний балансовий підхід до розрахунку обсягів надходження й використання зерна у Волинській області, згідно з яким, річна регіональна потреба в продовольчому зерні у період розробки регіональної програми становила 138,8 тис. т, у тому числі для сільського населення - 84,4 тис. т, для хлібопекарських підприємств усіх форм власності, підприємств із виробництва макаронів та круп, бюджетних закладів - 54,4 тис. т (у тому числі 44,4 тис. т. пшениці та 10,0 тис. т жита).

Таким чином, була визначена потреба хлібопекарських підприємств області в продовольчому зерні, що відповідає граничному (пороговому) критерію (60 днів) (4):

$$
H=54,4 * 17 \%=9,2 \text { тис. т. }
$$

Прийняття регіональної програми дозволило сформувати регіональний страховий запас продовольчого зерна в області в обсязі 9,2 тис. тонн.

Кошти обласного бюджету, відповідно до Порядку використання, коштів затвердженого рішенням Волинської обласної ради від 31.05.13 №19/21, спрямовуються на фінансову підтримку операторів через механізм здешевлення кредитів, одержаних операторами й спрямованими на закупівлю зерна в сільгосптоваровиробників області. Закупівля продовольчого зерна здійснюється як за спотовими, так і за форвардними контрактами. Форварді закупівлі $\epsilon$ ефективним механізмом фінансової підтримки сільгосповаровиробників області на ключових стадіях сільськогосподарського виробництва. Ціна на зерно в такому випадку фіксована й сформована виключно за ринковим принципом, виходячи з попиту, пропозиції та рентабельності виробництва.

Спотові закупівлі відбуваються за цінами рівноваги в межах коридору, затвердженими Міністерством аграрної політики та продовольства України, мінімальними й максимальними інтервенційними цінами.

Фінансова підтримка операторів відбувається методом часткового відшкодування відсотків у розмірі відсоткової ставки кредиту або комісії фінансової установи, але не більше від розміру подвійної облікової ставки Національного банку України.

На здешевлення кредитів, що використовуються операторами на закупівлю продовольчого зерна для потреб області, програмою передбачено 2,7 млн грн щорічно.

Як свідчать розрахунки, використовуючи середній рівень закупівельних цін на продовольче зерно, затверджений відповідними наказами Міністерства аграрної політики та продовольства України, використовуючи коштів обласного бюджету на пряму закупівлю зерна, передбаченої суми вистачило б лише на закупівлю близько 1,4 тис. т зерна при необхідному обсязі у 9,2 тис. т.

Тому механізм використання коштів обласного бюджету на здешевлення кредитів за допомогою часткового відшкодування відсотків є виправданим і дає змогу залучити необхідний обсяг комерційних ресурсів та сформувати регіональний страховий запас продовольчого зерна з мінімальними бюджетними затратами.

Сформований регіональний страховий запас в області дозволяє регулювати цінову ситуацію не лише на ринку зерна, а й на ринку хліба й хлібобулочних виробів. Борошно, вироблене із зерна регіонального страхового запасу, розподіляється між хлібопекарськими підприємствами області, які випікають хліб і хлібобулочні вироби, що користуються найвищим споживчим попитом в області, насамперед хліб простої рецептури, який доступний за ціною для всіх верств населення. Борошно також може 
бути розподілене для задоволення потреб бюджетних закладів.

Крім того, запровадження форвардних закупівель забезпечує формування цивілізованого аграрного ринку та реалізацію гарантованого права виробникам продовольства на безпосереднє отримання доходів від діяльності. Сформований 60денний запас продовольчого зерна уможливлює безперебійне забезпечення населення області хлібом і хлібобулочними виробами за доступними цінами, гарантування продовольчої безпеки в регіоні.

Розроблений механізм формування регіонального страхового запасу продовольчого зерна у Волинській області доцільно використати й іншим регіонам України, що дасть можливість гарантувати одну 3 найважливіших складових продовольчої безпеки - це достатність запасів зерна для потреб регіону впродовж маркетингового періоду.

Аналогічно регіональні страхові запаси інших видів продовольства мають формуватися на підставі балансових розрахунків та рівня забезпеченості внутрішніх потреб власною продукцією, яку пропонуємо розраховувати за формулою (5)

$$
W i=\frac{\mathrm{Pi}+\mathrm{Zi}}{S i+V i}
$$

де: Wi - відсоток забезпечення внутрішніх потреб у і-му виді продовольства;

$\mathrm{Pi}$ - виробництво і-го виду продовольства;

$\mathrm{Zi} \mathrm{-} \mathrm{зміна} \mathrm{запасів} \mathrm{на} \mathrm{кінець} \mathrm{року} \mathrm{і-го} \mathrm{виду} \mathrm{продовольства} \mathrm{в} \mathrm{регіоні;}$

$\mathrm{Si}$ - фонд споживання і-го виду продовольства в регіоні;

$\mathrm{Vi} \mathrm{-} \mathrm{витрати} \mathrm{і-го} \mathrm{виду} \mathrm{продовольства} \mathrm{в} \mathrm{регіоні} \mathrm{не} \mathrm{на} \mathrm{харчові} \mathrm{цілі.}$

В залежності від виду продовольства V може включати: витрати на корм, насіння, переробку та інші цілі.

Висновки. Таким чином, в умовах адміністративно-територіальної реформи та передачі відповідальності за планування та реалізацію ресурсного забезпечення від центральних до регіональних органів влади, забезпечення усіх складових продовольчої безпеки має відбуватися на регіональному рівні, що дає змогу оперативно реагувати на виклики та ефективного використовувати усі види ресурсів.

В умовах пандемій та вимушених обмежень необхідно забезпечити відкритість та нерозривність ланцюгів постачання з метою безперебійного функціонування суб'єктів торгівлі сільськогосподарською продукцією та продовольством, що відіграє важливу роль у запобіганні продовольчої нестабільності.

Регіональним органам влади необхідно утримуватись від запровадження необгрунтованих торговельних бар'єрів щодо сільськогосподарської продукції, продовольства та ключових ресурсів сільськогосподарського виробництва, а також розглядати можливість підтримки діяльності з виробництва продовольства.

У випадку запровадження надзвичайних заходів щодо сільськогосподарської продукції та продовольства, призначених для боротьби з COVID-19, застосування таких заходів повинно бути цілеспрямованим, пропорційним, прозорим, тимчасовими, відповідати правилам угод СОТ, а також не створювати невиправданих бар'єрів для торгівлі чи порушувати ланцюги постачання.

Регіональні рішення мають грунтуватися на діалозі та бути науково обгрунтованими, що дозволить покращити рівень готовності та спроможності реагувати на регіональні чи міжнародні пандемії.

Таким чином, регіональні баланси є тими інструментами, що забезпечують доступу до актуальної інформації щодо рівня виробництва, споживання, наявних запасів та дозволяють проводити регулярний моніторинг ситуації в регіоні та приймати зважені рішення, а регіональні запаси продовольства - гарантувати продовольчу безпеку на 
регіональному рівні.

\section{Список бібліографічного опису}

1. Постанова КМУ від 05.12.07 № 1379 «Деякі питання продовольчої безпеки» [Електронний ресурс]. - Режим доступу: https://zakon.rada.gov.ua/laws/show/ 1379-2007-\%D0\%BF\#Text

2. Закону Украӥни від 04.06.09 № 1447 «Про внесення змін до деяких законів Украӥни щцодо вдосконалення механізмів державного регулювання ринку сільськогосподарської продукиїі» [Електронний ресурс]. - Режим доступу: https://zakon.rada.gov.ua/laws/show/1447-17

3. Закон Украӥни від 24.06.04 № 1877-IV «Про держсавну підтримку сільського господарства Украӥни» [Електронний pecypc]. - Режим доступу: http://zakon.rada.gov.ua/cgi-bin/laws/main.cgi?nreg=1877-15

4. Постанова КМУ від 23.06.10 N 503 «Про затвердження Порядку використання кочтів, передбачених у державному бюджеті на формування Аграрним фондом державного інтервениійного фонду» [Електронний ресурс]. - Режим доступу: https://zakon.rada.gov.ua/laws/show/503-2010-\%D0\%BF\#Text

5. Закону України від 04.07.02 N 37-IV «Про зерно та ринок зерна в Україні» [Електронний ресурс]. - Режим доступу: https://zakon.rada.gov.ua/ laws/show/37-15\#Text

6. Рішення Волинської обласної ради від 24.05.13 №19/4 «Про затвердження Програми створення регіонального страхового запасу продовольчого зерна у Волинській області на 2013-2014 та наступні маркетингові періоди» [Електронний ресурс]. - Режим доступу: http://volynrada.gov.ua/session/19/4

7. Рішення Волинської обласної ради від 31.05.13 №19/21 «Про затвердження порядку надання і використання коштів обласного бюджету на фінансування Програми створення регіонального страхового запасу продовольчого зерна у Волинській області на 2013-2014 та наступні маркетингові періоди» [Електронний ресурс]. - Режим доступу: http://volynrada.gov.ua/session/19/21

8. Головне управління статистики у Волинській області : офіційний веб-сайт: URL: http://www.lutsk.ukrstat.gov.ua

9. Державна служба статистики Украӥни : офіційний веб-сайт: URL: http://www.ukrstat.gov.ua.

\section{References}

1. Postanova KMU vid 05.12.07 № 1379 «Deyaki pytannya prodovol'choyi bezpeky» [Resolution of the Cabinet of Ministers of Ukraine 05.12.07 № 1379 "Some issues of food security"] [Elektronnyy resurs] [Electronic resource]. - Rezhym dostupu [Access mode]: https://zakon.rada.gov.ua/laws/show/1379-2007-\%D0\%BF\#Text [in Ukrainian].

2. Zakonu Ukrayiny vid 04.06.09 № 1447 «Pro vnesennya zmin do deyakykh zakoniv Ukrayiny shchodo vdoskonalennya mekhanizmiv derzhavnoho rehulyuvannya rynku sil's'kohospodars'koyi produktsiyi» [Law of Ukraine of 04.06.09 № 1447 "On amendments to some laws of Ukraine to improve the mechanisms of state regulation of the market of agricultural products"]. [Elektronnyy resurs] [Electronic resource] - Rezhym dostupu [Access mode]: https://zakon.rada.gov.ua/laws/show/1447-17 [in Ukrainian].

3. Zakon Ukrayiny vid 24.06.04 № 1877-IV «Pro derzhavnu pidtrymku sil's'koho hospodarstva Ukrayiny» [Law of Ukraine of 24.06.04 № 1877-IV "On state support of agriculture of Ukraine"]. - Rezhym dostupu [Access mode]: http://zakon.rada.gov.ua/cgi-bin/laws/main.cgi?nreg=1877-15 [in Ukrainian].

4. Postanova KMU vid 23.06.10 N 503 «Pro zatverdzhennya Poryadku vykorystannya koshtiv, peredbachenykh u derzhavnomu byudzheti na formuvannya Ahrarnym fondom derzhavnoho interventsiynoho fondu» [Resolution of the Cabinet of Ministers of 23.06.10 N 503 "On approval of the Procedure for the use of funds provided in the state budget for the formation of the State Intervention Fund by the Agrarian Fund "] [Elektronnyy resurs] [Electronic resource]. - Rezhym dostupu [Access mode]: https://zakon.rada.gov.ua/laws/show/503-2010-\%D0\%BF\#Text [in Ukrainian].

5. Zakonu Ukrayiny vid 04.07.02 N 37-IV «Pro zerno ta rynok zerna v Ukrayini» ["On grain and grain market in Ukraine"] [Elektronnyy resurs] [Electronic resource]. - Rezhym dostupu [Access mode]: https://zakon.rada.gov.ua/ laws/show/3715\#Text [in Ukrainian].

6. Rishennya Volyns'koyi oblasnoyi rady vid 24.05.13 №19/4 «Pro zatverdzhennya Prohramy stvorennya rehional'noho strakhovoho zapasu prodovol'choho zerna u Volyns'kiy oblasti na 2013-2014 ta nastupni marketynhovi periody» [Decision of the Volyn Regional Council dated 24.05.13 №19 / 4 "On approval of the Program for the creation of a regional fund of food grain in the Volyn region for 2013-2014 and subsequent marketing periods"] [Elektronnyy resurs] [Electronic resource]. Rezhym dostupu [Access mode]: http://volynrada.gov.ua/session/19/4 [in Ukrainian].

7. Rishennya Volyns'koyi oblasnoyi rady vid 31.05.13 №19/21 «Pro zatverdzhennya poryadku nadannya $i$ vykorystannya koshtiv oblasnoho byudzhetu na finansuvannya Prohramy stvorennya rehional'noho strakhovoho zapasu prodovol'choho zerna u Volyns'kiy oblasti na 2013-2014 ta nastupni marketynhovi periody» [Decision of the Volyn Regional Council dated 31.05.13 №19 / 21 "On approval of the procedure for providing and using the regional budget to finance the Program of creating a regional fund of food grain in the Volyn region for 2013-2014 and subsequent marketing periods"] [Elektronnyy resurs] [Electronic resource]. - Rezhym dostupu [Access mode]: http://volynrada.gov.ua/session/19/21 [in Ukrainian].

8. Holovne upravlinnya statystyky u Volyns'kiy oblasti: ofitsiynyy veb-sayt [Main Department of Statistics in the Volyn region. Official website]. Retrieved from: http://www.lutsk.ukrstat.gov.ua [in Ukrainian].

9. Derzhavna sluzhba statystyky Ukrayiny: ofitsiynyy veb-sayt [State Statistics Service of Ukraine: official website]. Retrieved from: http://www.ukrstat.gov.ua [in Ukrainian].

Дата подання публікації 20.12.2020 p. 